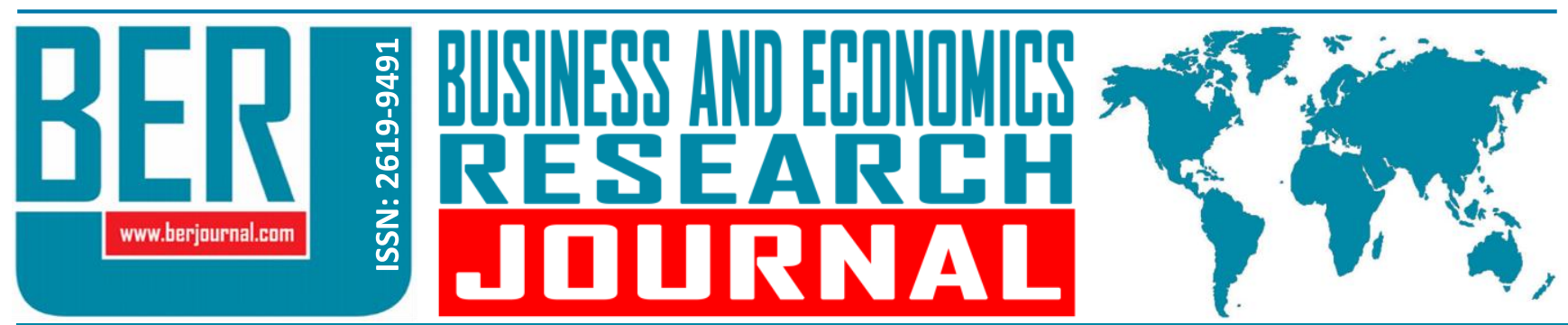

Business and Economics Research Journal Vol. 10, No. 4, 2019, pp. 777-788 doi: 10.20409/berj.2019.200

\title{
Analysis of the Causality Relationship between Brent Crude Oil Prices and Energy Import in Turkey Under Structural Breaks $^{1}$
}

\section{Esra N. Kilci ${ }^{\mathrm{a}}$}

Abstract: Turkey, struggling with the problem of high current account deficit, is an energy dependent country due to lack of oil reserves. Therefore, the changes in energy prices do have impacts on balance of payments through import channel. Considering that energy imports constitutes the biggest share of current account deficit, it is expected that the rise in oil prices will increase the imports upwards. The purpose of this study is to analyze the causality relationship from Brent crude oil prices to energy import by using the monthly data in the period of 2006:08-2018:12. The unit root properties of the series are tested by using Fourier KPSS (2006) unit root test and the causality relationship between the series is investigated by employing Fourier Granger (2016) causality test. Both these tests take into account the impact of multiple structural breaks. The results indicate that there is a causality relationship from Brent crude oil prices to energy import in Turkey in the relevant period.

Keywords: Crude Oil Prices, Energy Import, Current Account Deficit, Structural Breaks

JEL: C10, Q41, Q43

$\begin{array}{ll}\text { Received } & : \text { 20 June } 2019 \\ \text { Revised } & : 08 \text { July } 2019 \\ \text { Accepted } & : \text { 18 July } 2019 \\ \text { Type } & : \text { Research }\end{array}$

\section{Introduction}

Energy sector plays a very important role in the economic development of countries. While stable energy prices contribute to economic growth, rising energy prices negatively affect economic performance and some other macroeconomic indicators. Especially in the economies like Turkey which imports energy significantly, the upward trend in energy prices put pressure on domestic inflation and reduce foreign exchange reserves. The depreciation of national currency lead to a decrease in purchasing power of economic agents and makes energy import more expensive (Lescaroux \& Mignon, 2008).

Oil, one of the most important energy sources in the world, is used not only as raw material in the world economy but also as intermediate and final good in especially textile, defense industry and transportation sectors. Therefore, the fluctuations in oil prices are of great importance for the economies in the world and the changes in oil prices affect the oil-dependent countries considerably. Since almost every sector in an economy is dependent on oil, the changes in oil prices are closely taken into consideration by policy makers and researchers. On the other hand, fluctuations have different impacts on the importing or exporting economies. Increases in oil prices lead to income transfer from oil importing economies to oil exporting economies. In this regard, it can be said that oil exporting economies raise their real incomes in contrast to the oil importing economies due to the increases in oil prices. Furthermore, the increases in oil 
prices cause inflation, current account deficits and budget deficits in the oil importing economies (Alagoz, Alacahan, \& Akarsu, 2017).

Fluctuations in oil prices draw attention to the sustainability of oil production and its effects on the economies. Because the oil suply shocks lead to significant decreases in production, which bring with several problems such as negative growth, decreases in export and high unemployment. The high dependence on energy, which is an indispensable factor for the industrializing countries, has been increasing gradually and the energy need has been provided from fossil fuels especially from oil. Global reserves, which are not equally distributed geographically, differences in oil extraction costs, imbalances in oil supply and demand lead to fluctuations in oil prices. In addition, the reduction of the reserve life of these resources and the environmental destruction they cause has prompted countries to investigate alternative energy sources. Considering all these factors, both the directions of oil prices and the impacts of the price changes on the economies attract the attention of the researchers greatly. Oil importing economies have a high sensivity to price changes in oil. Because the price fluctuations have several economic effects by increasing cost of oil import (Sengonul, Karadas, \& Kosaroglu, 2018).

It is quite essential to evaluate the impacts of high oil prices on economies separately in terms of oil importing and oil exporting countries. First of all, high oil prices lead to a decrease in the real GDP's of oil importing countries as emphasized above. Since oil consumption can not be reduced in line with the rate of increase in oil prices, total oil expenditures increase, thus decreasing the amount of national income which will be allocated to the other expenditures. In this context, the adverse impact of high oil prices on national income of a country varies according to the share of oil expenditures in national income and the country's dependence on oil. In other words, if the share of oil expenditures in the national income is high in a country and the ability of this country to reduce oil consumption and to benefit from the other energy sources is limited, the negative impact of high oil prices on the economy generally increases. On the other hand, high oil prices have important implications for macroeconomic objectives and especially for the results of policies which aim to adapt the economy to rising oil prices. High oil prices directly increase the prices of input and raw materials in the world thereby increase the cost of production. Therefore, as producer and comsumer price inflation rises, inflation programs tended to aim to reduce the domestic demand. However, as a result of policies implemented for this purpose, investments and tax revenues might decrease (Ozkaya, 2001).

Turkey, having the highest current account deficit in the world with the other emerging markets as Argentina, Brazil, Colombia and South Africa in 2018, is a energy dependent country due to insufficient oil reserves and the changes in energy prices do have impacts on balance of payments through import channel. Considering that energy imports constitutes the biggest share of current account deficit, it is expected that the rises in oil prices will increase the imports upwards. The purpose of this study is to analyze the causality relationship from Brent crude oil prices to energy import by using the monthly data obtained from the Central Bank of the Republic of Turkey Electronic Data Delivery System in the period of 2006:08-2018:12. The unit root properties of the series are tested by using Fourier KPSS (2006) unit root test and the causality relationship between the series is investigated by employing Fourier Granger (2016) causality test. Both these tests take into account the impact of multiple structural breaks in the analysis.

Although there are several studies that concentrate on the impacts of crude oil prices on macroeconomic indicators in developed economies, it is seen that the literature focusing on the relationship between crude oil prices and macroeconomic fundamentals is limited in emerging market economies, particulary for oil importer economies like Turkey. This paper is one of the studies which analyse systematically the causality relationship from crude oil prices to energy import in Turkey by modelling the variables under the Fourier framework. In this way, we appropriately take into consideration multiple structural breaks without a need of the number, form or date of these breaks.

The remaining of the paper is constructed as follows: after briefly reviewing the developments in crude oil prices and the impacts of these in the current account balance in Section 1, Section 2 focuses on the studies in the academic literature that investigate the relationship between oil prices and macro 
economic indicators. While Section 3 introduces empirical analysis, Section 4 includes conclusion and some policy implications regarding the subject.

\section{The Developments in Crude Oil Prices and the Impacts of These in the Current Account Balance in Turkey}

Substantial changes in the oil prices in the last twenty-year-period have brought forward discussions concerning the impact of oil prices on the macroeconomic indicators such as economic growth, inflation and foreign exchange rates. It is seen that price fluctuations lead to shifts in real income between the oil importer countries and oil exporter countries. Current account deficit, a very important indicator which shows the vulnerability of a country against financial shocks, is mainly affected by changing oil prices and Turkey's reliance on energy import is a major factor behind its bloated current account deficit (Ozata, 2015). Therefore, the impacts of price changes on Turkey's external balance are taken into consideration and analyzed widely. When considered the high proportion of the energy especially of the crude oil in Turkey's imports, these analyses become quite important.

The crude oil prices have followed a very volatile trend since the beginning of the 2000 's. The price of brent crude oil, which was around 30 U.S dollar at the begining of the 2000's, increased rapidly since 2004 and reached 130 U.S dollar before the 2008-09 Financial Crisis. In the crisis period, it was seen that the crude oil price decreased to 40 U.S dollar. In the following period after 2008-09 Financial Crisis, which was also referred to as the second great recession, the crude oil prices started an upward trend and reached 100 U.S dollar and have been following a complex trend since 2014. When analyzed the energy import of Turkey, it has been seen that the crude oil import followed a stable trend until 2008-09 Financial Crisis. The crude oil import, which decreased significantly due to the economic stagnation caused by the economic crisis, reached 7 million tons with the increase in domestic demand as a result of stable growth in GDP in the post-crisis period. According to the data announced by International Energy Agency, Turkey's crude oil import dependence was realized as 94,4 percent as of 2015. In the same year, it has been seen that Turkey imported 45.4 percent of its crude oil from Iraq and 22.2 percent of it from Iran. Obviously, Turkey is a net importer of energy and the energy import has serious impacts on the current account deficit. Therefore, the changes in the oil import have determining effects in terms of balance of payments (Kal \& Kaplan, 2018).

Graph 1: Brent Crude Oil Prices and Energy Import (2006-2018)

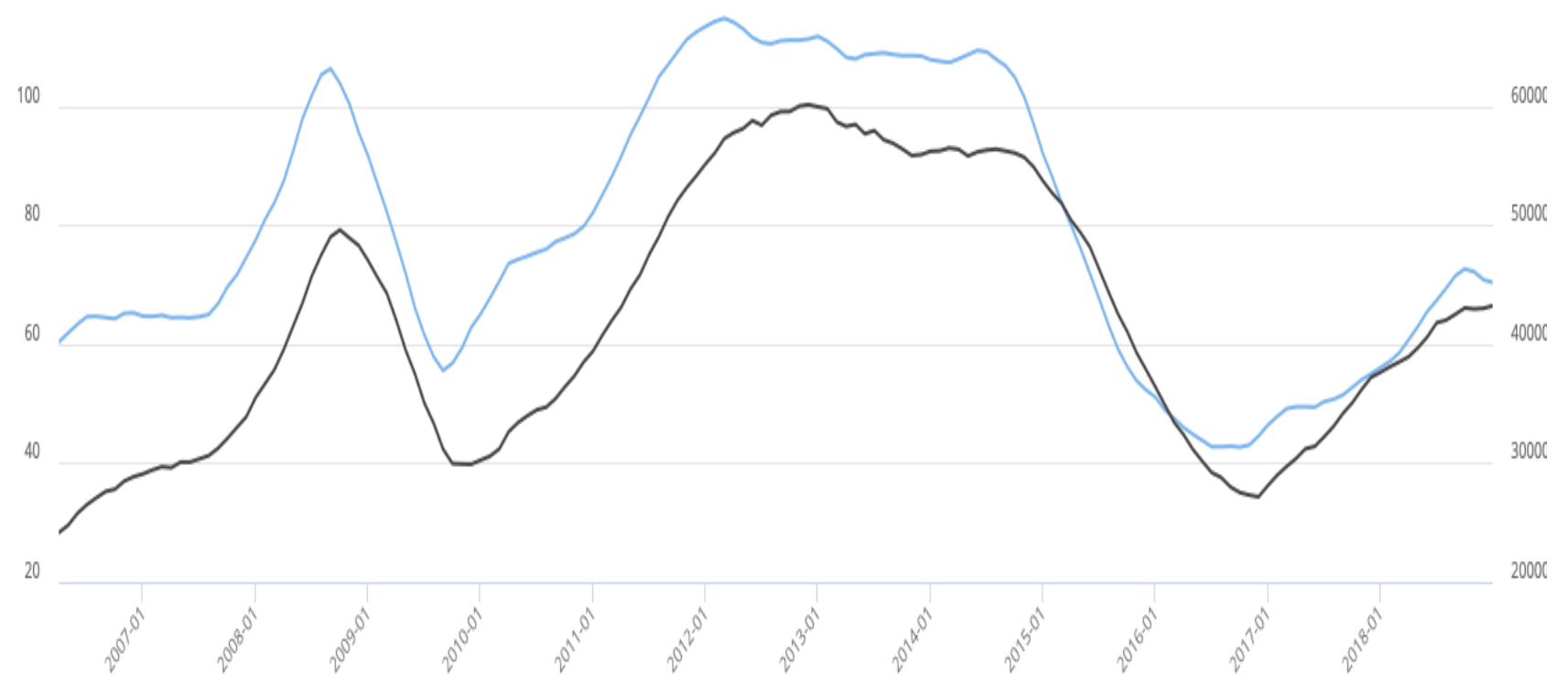

Source: CBRT Electronic Data Delivery System

Brent Crude Oil Prices $=$ Energy Import 
In the recent period, there has been seen an upward trend and while the increases in oil prices contribute positively to the countries like Iran, Iraq, Kuwait, Saudi Arabia and Russia, of which economies are supported by oil exports, these increases adversely affect the economies of oil importing countries like Turkey and some member countries of European Union. In the year of 2018, the rise in energy prices particulary in crude oil prices, continued to affect the current account balance negatively. However, the deceleration in domestic demand limited the deterioration in the current account balance excluding gold and energy. Commodity prices, which were traded in international markets, maintained their upward trend in the second quarter of 2018, mainly driven by energy and industrial metal prices. The crude oil price assumption, which was used in the medium-term forecasts, increased to 73 U.S dollar from 68 U.S dollar for 2018 and to 73 U.S dollar from 65 U.S dollar for 2019, based on the upward trend in crude oil prices in the second quarter. In this period, in addition to the foreign exchange rate effects, the increase in international oil prices was also felt in the significant acceleration in energy inflation (CBRT Inflation Report, 2018).

\section{Literature Review}

There are several studies in the academic literature focusing on the impacts of oil prices on macroeconomic or financial indicators of the economies. It is seen that most of the studies investigate the effects of oil prices on spesific factors like inflation, economic growth and foreign exchange rates. On the other hand, the literature on the relationship between crude oil prices and current account balance or imports-exports is limited, particularly for oil importer countries like Turkey. Below are briefly explained the studies which investigate the relationship between oil prices and both macroeconomic indicators and current account components.

Chen and Chen (2007) analyzed the long-run relationship between the real oil prices and the real exchange rates by using the panel data covering G7 countries for the period of 1972- 2005. After employing a panel cointegration test and panel prediction regression, they found that the real oil prices might have been the major source of real exchange rate fluctuations and there was a link between them during this period. They also investigated the ability of real oil prices to predit future real exchange returns and their findings suggested that real oil prices had significant forecasting power in forecasting real exchange returns. Demirbas et al. (2009) tried to examine the relationship between crude oil prices and current account deficit in Turkey. Their findings supported the long-run relationship between the variables. Accordingly, increases in crude oil prices do have positive impact on current account deficit. They emphasized that Turkey's oil import expenditures would increase strictly and it would lead to rise in current account deficit in the future in case of the upward trend in global oil prices.

Lizardo and Mollick (2010) investigated the relationship between oil prices and foreign exchange rates by using the variables such as U.S relative industrial production, U.S relative money supply, U.S dollar exchange rate and the other currencies of oil importing and oil exporting countries in their cointegrated VAR model. They concluded that crude oil prices significantly explained the changes in the value of U.S dollar against the other major currencies in the long-run. In other words, their findings indicated that increases in real oil prices led to a substantial depreciation in the value of U.S dollar against the currencies of oil exporting countries like Canada, Russia and Mexico. On the other hand, these increases resulted in an appreciation in U.S dollar against the currencies of oil importing countries like Japan. Ozlale and Pekkurnaz (2010) analyzed the net impact of oil prices on the current account balance for the Turkish economy by employing a structural vector autoregression model. After including the other factors such as exchange rate misalignment and output gap, they found that the response of current account ratio to oil price shocks increased gradually up to the first three months and then started to lower, which indicated a significant impact of oil price shocks in the short-run. Furthermore, when they employed the structural shocks in their analysis, the oil price shock parameter was found to be statistically significant and negative.

Catik and Karacuka (2012) tested the existence of oil prices transmission to inflation under several inflation regimes in Turkey. They employed Markov Regime Switching Vector Autoregressive (MS-VAR) model as a non-linear estimation framework with the objective of comparing the differences between the oil passthrough impacts in the high and low inflation periods. According to their results, the regime-dependent 
impulse responses did not signal to a strong pass-through from crude oil prices to inflation in both regimes. On the other hand, they found that this channel worked through refined petroleum product prices. The findings signaled that there was a considerable decline in the pass-through mechanism from refined petroleum prices to inflation as the economy moved from high to low inflation regime. Yaylali and Lebe (2012) examined the impacts of changes in crude oil prices on macroeconomic activities for Turkish economy in the period of 1986:Q2-2010:Q2 by employing VAR methodology. They found that crude oil prices were more effective in monetary policy decisions and crude oil prices and monetary policy were the main sources of changes in general level of prices. Therefore, crude oil prices were one of the important source of inflation in Turkey.

Altintas (2013) analyzed the relationship between oil prices and foreign trade in the period of 19872010 by using the variables such as exports, real oil prices and real exchange rates and by employing the ARDL methodology and Granger causality tests. He found that there was a long-run relationship between exports and oil prices; that is a 1 percent increase in real oil prices would lead to 0.22 percent increase in exports. The results of the Granger causality test indicated that Turkey's exports was more sensitive to external economic developments. Zhang (2013) examined the long-run relationship between the real oil prices and real effective exchange rate of U.S dollar under structural breaks. After suggesting that the relationship between the variables was subject to structural breaks over time although there was a stable relationship, he found that the long-run relationship between the real oil prices and real effective exchange rate did not significantly exist unless the effects of two structural breaks (November, 1986 and February, 2005) were controlled.

Ozata (2014) investigated the impacts of fuel import and foreign exchange policy on Turkey's economic growth and current account deficit by employing the SVAR model which allowed for simultaneous analysis of the relationship between real oil imports, current account balance, real effective exchange rate and national income. He showed that overvalued Turkish Lira and economic growth were the major causes of current account deficit and this was resulting from the dependency of the production on the imported intermediate goods and increase in the private consumption of imported goods. He also found that oil import had a significant positive effect on the current account deficit that was an expected result for a developing country which was dependent on foreign energy and used imported oil in the production process. Yalcin et al. (2014) analyzed the impacts of unexpected oil price changes on Turkish economy by using quarterly GDP (gross domestic product), monthly CPI (consumer price index) and RER (real effective exchange rate) for the period of 2002-2013. They employed asymmetric vector autoregressive methodology developed by Kilian and Vigfusson (2011) in order to test the asymmetric effect of oil prices on macroeconomic variables. This method allowed them to examine the asymmetric impacts of innovations in oil prices on macroeconomic aggregates without knowing data generating process was linear or not. Their findings indicated that the oil prices changes had asymmetric impacts on CPI and RER. Specifically, they found that CPI and RER increased but GDP decreased in the long-run when oil prices increased.

Culha et al. (2015), examined the impact of the sharp decreases observed in oil prices on commodity exports rates of Turkey. After analyzing the effect of oil prices on economic growth of the trade partners of Turkey at the first step, it was found that the impact of oil prices on different country groups' growth was asymmetric. Then estimating the growth-export elasticity for two groups of countries through Turkey's export demand function, they found that the income flexibility of the exports of Turkey to countries that exported oil was extremely lower than the income flexibility of the countries that imported oil. Their finding also indicated that the net impact of the changes in oil prices on the export rates of Turkey was limited when the shares of the country groups in Turkey's exports were taken into consideration. Chen et al. (2016) empirically investigated the effects of political risk of OPEC countries on Brent crude oil prices. They found that the OPEC's political risk did have a positive and significant impact on Brent crude oil prices and OPEC's integrated political risk contributed 17.58 percent to the oil price fluctuations in the sample period. They showed that oil price shocks resulting from supply or demand shocks might explain nearly 20 percent of longterm variations in U.S dollar exchange rates and the explanation power became much bigger after the 200809 Global Financial Crisis. 
Basarir and Ercakar (2016) analyzed the impact of Brent crude oil prices and foreign exchange rates on current account deficit of the Turkish economy in the period of 1991:12-2016:01 by employing the VAR model. They found that while there was a long-run relationship between all the variables, a mutual Granger causality was found only between crude oil prices and current account deficit. Adam et al. (2018) tried to analyze the causal relationship between crude oil prices, foreign exchange rates and rice prices by using monthly data covering the period of 2000:01-2017:09 and by employing vector autoregressive model. Based on the data analysis results, they found that there was no long-term relationship between crude oil prices, IDR/EUR exchange rates and the rice prices. In addition, the Granger causality test results supported the single way causality relationship from crude oil prices and IDR/EUR exchange rates to rice prices. Sengonul et al. (2018) examined the impact of oil prices on the exports of Turkey by taking into account the recent changes in oil prices. Their findings indicated that the oil prices and the exports moved in the same direction.

Liao et al. (2018) tested the relationship between crude oil prices and the U.S dollar index by employing DCC-GARCH model. They found that the dynamic relationship between crude oil prices and the US dollar index was time-varying, showing a process of "very weak correlation-negative correlation-enhanced negative correlation and weakening negative correlation" since 1990. According to their findings, the correlation was weak before 2002; oil prices and the dollar index respectively exhibited a significant rise and declining trend between 2002 and 2008, triggerring a market hedge strategy; financial market sentiment had become intermediary of negative relationship as crude oil and U.S dollar were seen as risky and risk-aversion asset independently after the breakout of the global financial crisis; maintained at a high level until 2013 and the lack of a common key mediating factors brougt with a weak correlation in the other periods.

\section{Empirical Analysis}

\subsection{Data and Methodology}

In this study, the causality relationship from the Brent crude oil prices to the energy import of Turkey, an oil importer economy and highly dependent on energy, is tried to be investigated. The analysis is carried out by using monthly data of Brent crude oil prices and energy import which are obtained from the CBRT Electronic Data Delivery System for the period of 2006:08-2008:12. In the first stage, Fourier KPSS unit root test is employed to test the stationary of the variables. The Fourier test proposed by Becker et al. (2006) can both detect sudden changes and smooth changes. On the meantime, the position, number and form of structural changes do not affect the power of the test. In the following stage, Fourier Granger causality test is employed to test the causality relationship between energy import and Brent crude oil prices. The VAR with Fourier Frequencies, which is developed by Enders and Jones (2016), yields powerful results in the analysis. After putting trigonometric functions into the model, Enders and Jones (2016) detected a richer set of interactions between the variables.

Table 1. Variables and Expected Relationship

\begin{tabular}{lllc}
\hline & Variables & Measure & $\begin{array}{c}\text { Expected } \\
\text { Relationship }\end{array}$ \\
\hline Dependent Variable & Energy Import & Energy Import (Million USD) & $(+)$ \\
Independent Vaiable & Brent Crude Oil Prices & $\begin{array}{l}\text { Europe Brent Spot Price FOB } \\
\text { (Dollars per Barrel) }\end{array}$ & $(+)$ \\
\hline
\end{tabular}

As seen at Table 2, the crude oil prices have the minimum value of 33.14 USD (2016:01) and the maximum value of 138.40 (2008:06) while the energy imports have the minimum value of $1,898.89$ million USD (2009:04) and the maximum value of 5,416.95 million USD (2012:03) in the period of 2006:08-2018:12. According to descriptive statistics, it is seen that crude oil prices and energy import reach monthly average of 79.73 USD and 3,581.18 million USD, respectively. Both the skewness and kurtosis of crude oil prices and energy import series support that the series are not normally distributed but this condition is generally being 
ignored in studying with financial series. In addition, it is seen that the standard deviation which denotes volatility is 26.23 for crude oil prices and 961.78 million USD for energy import.

Table 2. Descriptive Statistics of the Variables

\begin{tabular}{lcc}
\hline & Oil Prices & Imports \\
\hline Mean & 79.73 & $3,581.18$ \\
Median & 75.92 & $3,474.62$ \\
Maximum & 138.40 & $5,416.95$ \\
Minimum & 33.14 & $1,898.89$ \\
Std. Dev. & 26.23 & 961.78 \\
Skewness & 0.147 & 0.148 \\
Kurtosis & 1.76 & 1.76 \\
Jarque-Bera & 9.97 & 10.06 \\
Probability & 0.006 & 0.006 \\
Observations & 149 & 149 \\
\hline
\end{tabular}

\subsection{Analysis and Results}

Since there is generally no specific information relating to the definite nature of the breaks and no practical knowledge about the location and the number of breaks to use in testing for stationary, using an incorrect specification for the number or form of breaks might create some dilemma such as ignoring the breaks together. Becker et al. (2006) developed a stationary test in which a chosen frequency component of a Fourier function was used to estimate the deterministic components of the model. A Fourier series could effectively model the behavior of an unknown function even though this function is not regular. In this stationary test, that the Fourier function capturing the movements of the unknown function is the primary reason for applying it. The Fourier unit root test proposed by Becker et al. (2006) can detect both sudden changes and smooth changes. In the meantime, the position, number and form of structural changes do not affect the power of the test. For this reason, the performance of the tests was substantially robust to several kinds of structural breaks often seen in economic analysis, including the breaks of opposite signs (Tsong, 2016).

The methodology developed by Becker et al. (2006) seems strong to notice sharp and u-shaped breaks as well as smooth breaks near the end of a series and it functions best when breaks are gradual. Becker et al. (2006) employ trigonometric terms to capture unknown nonlinearities. The test they developed is a KPSS-type stationary test (Becker, Enders, \& Lee, 2006).

Becker et al. (2006) take into account the following DGP:

$$
\begin{aligned}
& y_{t}=X t^{\prime} b+Z t^{\prime} \gamma+r_{t}+\varepsilon_{t} \\
& r_{t}=r_{t-1}+u_{t}
\end{aligned}
$$

where $\varepsilon_{t}$ are stationary errors and $u_{t}$ are independent and identically distributed with variance $\sigma_{u}{ }^{2}$. It is chosen $Z_{t}=[\sin (2 \pi k t / T), \cos (2 \pi k t / T)]^{\prime}$ to catch a break in the deterministic term, where k represents the frequency and $T$ is the sample size. Here, to test whether $y_{t}$ is stationary or not, it is defined as $X_{t}=[1]$ for a level-stationary process for $y_{t}$ and $X_{t}=[1, t]^{\prime}$ for a trend-stationary process.

At the start, one of the models described below is estimated and the residuals are obtained, in order to acquire the t-statistic required for testing the null hypothesis $\left(\mathrm{H}_{0}=\sigma_{u}{ }^{2}=0\right)$; 


$$
\begin{aligned}
& y_{t}=\propto_{0}+\gamma_{1} \sin \left(\frac{2 \pi k t}{T}\right)+\gamma_{2} \cos \left(\frac{2 \pi k t}{T}\right)+e_{t} \\
& y_{t}=\propto_{0}+\beta t+\gamma_{1} \sin \left(\frac{2 \pi k t}{T}\right)+\gamma_{2} \cos \left(\frac{2 \pi k t}{T}\right)+e_{t}
\end{aligned}
$$

The following test statistics is obtained;

$$
\tau_{\mu}(k) \text { or } \tau_{\tau}(k)=\frac{1}{T^{2}} \frac{\sum_{t=1}^{T} \tilde{S}_{t}(k)^{2}}{\tilde{\sigma}^{2}}
$$

where $\tilde{S}_{t}(k)=\sum_{j=1}^{t} \tilde{e}_{j}$ and $\tilde{e}_{j}$ are the OLS residuals from the regression (2) for $\tau_{\mu}(k)$ or (3) for $\tau_{\tau}(k)$. As in KPSS, a nonparametric estimate $\tilde{\sigma}^{2}$ of the long-run variance could be acquired by selecting a truncation lag parameter $/$ and a set of weights $\mathrm{w}_{\mathrm{j}, \mathrm{j}}=1, \ldots, \mathrm{l}$;

$$
\tilde{\sigma}^{2}=\tilde{\gamma}_{0}+2 \sum w_{j} \tilde{\gamma}_{j}
$$

where $\tilde{\gamma}_{j}$ is the $j$ th sample auto-covariance of the residuals $\tilde{e}_{t}$ from equation (2) or (3).

To determine the optimal number of $k$, the value which gives the minimum sum of residuals (OLS) is being selected. In case the non-linear trend is not present in DGP, it can be applied the standard KPSS test in order to obtain increased power. As it seems useful to test for the absence of a non-linear trend, Becker et al. (2006) proposed that F-test statistic to be used. Therefore, the following F-test statistic for this hypothesis (absence of a nonlinear trend (i.e. $\gamma_{1}=\gamma_{2}=0$ ) can be calculated against the alternative of a nonlinear trend with a given frequency $k$.

$$
F_{i}(k)=\frac{\left(S S R_{0}-S S R_{1}(k)\right) / 2}{S S R_{1}(k) /(T-q)} \quad \mathrm{i}=\mu, \tau,
$$

The F-test could be used only if the null of stationary is rejected. The standard KPSS test statistic would be used in case trigonometric terms are not significant. In comparison with the critical values related to Fourier test which are shown in the study of Becker et al. (2006), the results of the stationary test are stated below.

Table 3. Stationary Test Results ( $T=149)$

\begin{tabular}{lcccc}
\hline Variable & Frequency & MinSSR & FKPSS & F-Statistic \\
\hline Imports & 1 & 81715.61 & $0.082797^{*}$ & $49.301^{* * *}$ \\
Oil Prices & 1 & 57003.30 & $0.072010^{*}$ & $57.462^{* * *}$ \\
\hline$\tau_{\mu}(k)-$ Level & FKPSS Critical Values & & F-Statistic Critical Values \\
\hline $1 \%$ & 0.2709 & 6.281 \\
$5 \%$ & 0.1696 & 4.651 \\
$10 \%$ & 0.1294 & & 3.935 \\
\hline Notes: ${ }^{* * *},{ }^{* *}$, and & & \\
\hline
\end{tabular}

As seen in the Table 3, the IMPORTS and the BRENT variables are stationary. According to the F-test results, which are used to test the significancy of the trigonometric terms, it seems that trigonometric terms for both variables are significant when the values are compared with the F-statistic critical values which are shown in the study of Becker et al. (2006). In the graphs below, it is clearly seen that the series belonged to Brent crude oil prices and energy import are stationary. 
Graph 2-3: Stationary of Brent Crude Oil Prices and Energy Import (2006-2018)
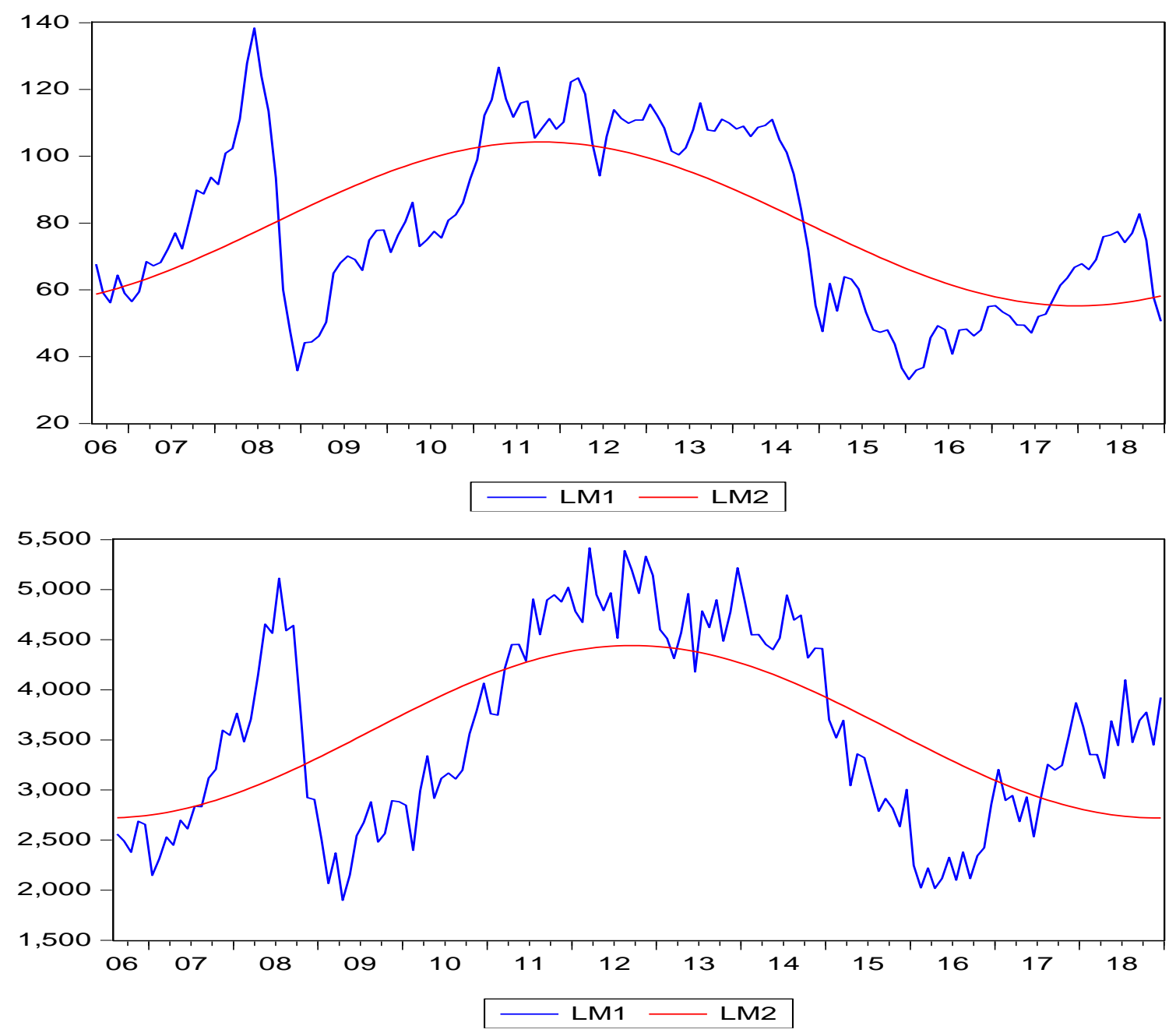

In the second stage, Fourier Granger causality test proposed by Enders and Jones (2016) is employed in order to investigate the causal linkages between Brent crude oil prices and energy import. The linkages between the variables are subjected to gradual shifts and it is seen that linear specifications are mostly inappropriate to capture the relationships. Therefore, econometric examinations are not generally simple and direct. Enders and Jones (2016) allows the Flexible Fourier form to catch the multiple smooth mean shifts that are probably to be present in the VAR system and focus on the short-term dynamics of the system through Granger-causality tests.

Rather than estimating the size, number and form of the breaks, Enders and Jones test the Flexible Fourier Form to control for breaks in a VAR and after they try the non-stationary of variables, they consider the linear VAR as following;

$$
z_{t}=\delta+\sum_{i=1}^{11} A_{i} z_{t-i}+e_{t}
$$

where $\delta$ is a (4x1) vector of intercepts, $A_{i}$ is a $(4 \times 4)$ coefficient vector and $e_{t}$ is the vector of innovations. Although the responses seem sensible, they have some complications for two reasons. First, to the extent that there are neglected structural breaks, the system given by (7) is misspecified. Second, given that an unrestricted VAR is probably to be overparameterized, the confidence intervals shown in the figure may be unnecessarily large. In order to show how neglected breaks can interfere with Granger causality tests, 
they pursue a standard recommendation and restrict the VAR by imposing the limitations implied by the Granger causality tests. Their results indicate that there is very little interaction among the variables. The significant responses are such that series tend to react only to their own shocks.

Then, Enders and Jones allow the deterministic regressors be as following, instead of the VAR given by (7);

$$
\begin{aligned}
& z_{t}=\delta(t)+\sum_{i=1}^{11} A_{i} z_{t-i}+e_{t} \\
& \delta(t)=\left[\delta_{1}(t), \delta_{2}(t), \delta_{3}(t), \delta_{4}(t)\right]^{\prime}
\end{aligned}
$$

and each intercept $\delta_{i t}$ depends on $\mathrm{n}$ Fourier frequencies such that;

$$
\delta_{i}(t)=a_{i}+b_{i} t+\sum_{k=1}^{n} a_{i k} \sin \left(\frac{2 \pi k t}{T}\right)+b_{i k} \cos \left(\frac{2 \pi k t}{T}\right)
$$

When the Fourier terms are used to control for breaks, the Granger causality results change from those recorded before in several important ways. In contrast to the Granger-causality results indicated by the linear VAR, when Enders and Jones (2016) put trigonometric functions into the model, they detect

\begin{tabular}{|c|c|c|c|c|}
\hline Optimal Frequency & Wald-stat & Asymptotic p-value & Bootstrap p-value & Optimal Lag \\
\hline 2 & 44.277 & $0.000 * * *$ & 0.000 & 1 \\
\hline 4 & 52.991 & $0.000 * * *$ & 0.000 & 1 \\
\hline \multicolumn{5}{|c|}{ Brent Crude Oil Prices $\rightarrow$ Energy Import (Single frequency) } \\
\hline $\begin{array}{l}\text { Notes: } \rightarrow \text { denotes to ca } \\
\text { criterion. Bootstrap p-va }\end{array}$ & $\begin{array}{l}\text { sality. Optim } \\
\text { ues are based }\end{array}$ & $\begin{array}{l}\text { (frequency) and } \mathrm{p} \text { (lag) } \\
1000 \text { replications. } * * *\end{array}$ & $\begin{array}{l}* \text { are determined by } A \\
\text {, and } * \text { denote } \% 1,9\end{array}$ & $\begin{array}{l}\text { ike information } \\
\text { and } \% 10 \text { levels }\end{array}$ \\
\hline
\end{tabular}
stronger relations and richer sets of interactions between the variables.

Table 4. Causality Test Results ( $\mathrm{T}=149)$

Table 4 shows the results of Fourier Granger causality test. According to the results, as asymptotic $p$ value is less than 0.05 in both single frequency and cumulative frequency, there seems to be a causality relationship from Brent crude oil prices to energy import. Therefore, it is seen that the changes in Brent crude oil prices do have impacts on energy import of Turkey.

\section{Conclusion}

Turkey's high dependence on energy and high current account deficit bring with adverse effects in terms of macroeconomic and financial outlook. The fluctuations in energy prices do have impacts on balance of payments throuh import channel. While increases in energy prices for oil importing economies like Turkey create a huge pressure on the current account deficit, price decreases contribute positively to the current account balance. The purpose of this study is to analyze the causality relationship from Brent crude oil prices to energy import by using the monthly data obtained from the Central Bank of Republic of Turkey Electronic Data Delivery System in the period of 2006:08-2018:12. The unit root properties of the series are tested by using Fourier KPSS (2006) unit root test and the causality relationship between the series is investigated by employing Fourier Granger (2016) causality test. Both these tests take into account the impact of multiple structural breaks in the analysis. The results indicate that there is a causality relationship from Brent crude oil prices to energy import in Turkey in the relevant period. 
Turkey's energy import, which shows an upward trend in the recent period as a result of both the volatiliy seen in oil prices and appreciation in foreign exchange rates against Turkish lira, constitutes the largest item in the current account deficit. The major reason of that Turkey is a net importer of energy since it does not have sufficient sources although it uses oil, coal and natural gas in heating, electricity production and transportation sector. Given that the upward trend of oil prices globally, it can be said that Turkey's payments for oil import increase and thereby current account balance would deteriorate in the future term. In order to minimize the current account deficit and its negative effects on the economy, it seems essential that alternative energy sources be taken into consideration more. Turkey can reduce its dependence on energy through diversification in resources and it can increase the share of renewable energy in overall production.

The importance and necessity of renewable energy sources such as solar and wind for countries in the world including Turkey is increasing. Therefore, investments in renewable energy should be increased, especially given the fact that climate changes have been felt severely. On the other hand, it is seen that the tendency towards renewable energy sources in Turkey is very low. When these alternative sources are effectively used in Turkey, it will contribute not only to the energy budget and hence the current account balance but will also significantly lead to decrease in greenhouse gas emissions.

\section{End Notes}

1. This paper is a revised and expanded version of a study entitled 'Analysis of the Relationship between Brent Crude Oil Prices and Energy Imports; Evidence from Turkey' presented at the V. European Congress on Economic Issues which was held on April 25-27, 2019 in Baku, Azerbaijan.

\section{References}

Adam, P., Wintag, R., Saidi, L. O., Tondi, O., \& Sani, L. O. A. (2018). The casual relationship between crude oil price, exchange rate and rice price. International Journal of Energy Economics and Policy, 8(1), 90-94.

Alagoz, M., Alacahan, N. D., \& Akarsu, Y. (2017). Petrol fiyatlarının makro ekonomi üzerindeki etkisi: Ülke karşılaştırmaları ile panel veri analizi. KMÜ Sosyal ve Ekonomik Araştırmalar Dergisi, 19(33), 144-150.

Altintas, H. (2013). Türkiye'de petrol fiyatları, ihracat ve reel döviz kuru ilişkisi: ARDL sınır testi yaklaşımı ve dinamik nedensellik analizi. Uluslararası Yönetim iktisat ve Işsletme Dergisi, 9(19), 1-30.

Basarır, C., \& Ercakar, M. E. (2016). An analysis of the relationship between crude oil prices, current account deficit and exchange rates: Turkish experiment. International Journal of Economics and Finance, 8(11), 1-13.

Becker, R., Enders, W., \& Lee, J. (2006). A stationarity test in the presence of an unknown number of smooth breaks. Journal of Time Series Analysis, 3(5), 381-409.

Catik, A. N., \& Karacuka, M. (2012). Oil pass-through to domestic prices in Turkey: Does the change in inflation regime matter? Ekonomskaistraživanja, 25(2), 277-296.

CBRT (2018). Enflasyon Raporu, 2018-III. https://www.tcmb.gov.tr/wps/wcm/connect/9338c1f9-5862-4686-bb221858a6b0b35d/enf-temmuz2018_tam.pdf?MOD=AJPERES\&CACHEID=ROOTWORKSPACE-9338c1f9-5862-4686bb22-1858a6b0b35d-msSBEgv (Access date: 15.03.2019).

CBRT (2019) Electronic Data Delivery System. https://evds2.tcmb.gov.tr/index.php?/evds/serieMarket (Access date: 05.03.2019).

Chen, S., \& Chen, H. (2007). Oil prices and real exchange rates. Energy Economics, 29, 390-404.

Chen, H., Liao, H., Tang, B. J., \& Wei, Y. M. (2016). Impacts of OPEC's political risk on the international crude oil prices: An empirical analysis based on the SVAR models. Energy Economics, 57, 42-49.

Culha, O., Ozmen, U., \& Yılmaz, E. (2015). Petrol fiyatlarının ihracat üzerindeki etkisi. TCMB Ekonomi Notları, 2015-10. http://www.tcmb.gov.tr/wps/wcm/connect/deae2ce6-dea3-46b3-9730-e8c22519fc4a/en1510.pdf?MOD=AJ PERES\&CACHEID=ROOTWORKSPACEdeae2ce6-dea3-46b3-9730-e8c22519fc4a

Demirbas, M., Turkay, H., \& Turkoglu, M. (2009). Petrol fiyatlarındaki gelişmelerin Türkiye'nin cari açığı üzerine etkisinin analizi. Süleyman Demirel Üniversitesi iiBF Dergisi, 14(3), 289-299. 
Enders, W., \& Jones, P. (2016). Grain prices, oil prices, and multiple smooth breaks in a VAR. Studies in Nonlinear Dynamics \& Econometrics, 20(4), 399-419.

Kal, S. H., \& Kaplan, Y. (2018). Türkiye'de ham petrol ithalat talebinin fiyat ve gelir esneklikleri: 2001-2017 Dönemi Ekonomi Notları, 2018-05. http://www.tcmb.gov.tr/wps/wcm/connect/71f0235b-c89d-42be-96a3671b4bafc7a2/en1805.pdf?MOD=AJPERES\&CACHEID=ROOTWORKSPACE-71f0235b-c89d-42be-96a3671b4bafc7a2-mjH5ryr

Lardic, S., \& Mignon, V. (2008). Oil prices and economic activity: An asymmetric cointegration approach. Energy Economics, 30, 847-855.

Liao, J., Shi, Y., \& Xu, X. (2018). Why is the correlation between crude oil prices and the US Dollar exchange rate timevarying? Explanations based on the role of key mediators. International Journal of Financial Studies, 6(61), 1-13.

Lizardo, R. A., \& Mollick, A. V. (2010). Oil price fluctuations and U.S. Dollar exchange rates. Energy Economics, 32, 399408.

Ozata, E. (2014). Sustainability of current account deficit with high oil prices: Evidence from Turkey. International Journal of Economic Sciences, III(2), 71-88.

Ozkaya, S. (2001). Petrol fiyatlarının ekonomilere etkisi. Uluslararası Ekonomik Sorunlar Dergisi, (1), http://www.mfa.gov.tr/petrol-fiyatlarinin-ekonomilere-etkisi.tr.mfa

Ozlale, U., \& Pekkurnaz, D. (2010). Oil prices and current account: A structural analysis for the Turkish economy. Energy Policy, 38(8), 4489-4496.

Sengonul, A., Karadas, H. A., \& Kosaroglu, S. M. (2018). Petrol fiyatlarının ihracat üzerindeki etkisi. Yönetim ve Ekonomi Dergisi, 25(2), 335-349.

Tsong, C. C., Lee, C. F., Tsai, L. J., \& Hu, T. C. (2016). The fourier approximation and testing for the null of cointegration. Empirical Economics, 51(3), 1085-1113.

Yalcin, Y., Arikan, C., \& Emirmahmutoglu, F. (2014). Determining the asymmetric effects of oil price changes on macroeconomic variables: A case study of Turkey. Empirica, 42(4), 737-746.

Yaylali, M., \& Lebe, F. (2012). İthal ham petrol fiyatlarının Türkiye'deki makroekonomik aktiviteler üzeribdeki etkisi. Marmara Üniversitesi i.i.B.F. Dergisi, XXXII(I), 43-68.

Zhang, Y. (2013). The links between the price of oil and the value of U.S Dollar. International Journal of Energy Economics and Policy, 3(4), 341-351. 